\title{
Surface and subsurface reworking by storms on a Cambrian carbonate platform: evidence from limestone breccias and conglomerates
}

\author{
Jitao Chen \\ Nanjing Institute of Geology and Palaeontology, Chinese Academy of Sciences, Nanjing 210008, China; \\ e-mail: jtchen@nigpas.ac.cn
}

\begin{abstract}
Some limestone breccias and conglomerates from the Furongian (Late Cambrian) Chaomidian Formation (Shandong Province, China) were investigated in order to understand the depositional and deformational processes induced by storms. The sediments under study occur in a hummocky cross-stratified peloidal grainstone layer. The limestone conglomerates consist of well-rounded clasts that are mostly flat-lying or imbricated, and have erosional bases. They formed by surface reworking (erosion and rip-up) of thin-bedded grainstones by storm waves and currents. The limestone breccias consist of subangular to subrounded clasts of grainstone, which are often associated with small-scale grainstone clastic dykes. The breccias and dykes resulted from subsurface soft-sediment deformation (i.e., differential liquefaction and fluidization of heterogeneously cemented carbonate grains), most likely triggered by storm-wave loading. The limestone breccias and conglomerates bear important implications for understanding the reworking mechanisms of storms on ancient carbonate platforms.
\end{abstract}

Keywords: limestone breccia, limestone conglomerate, soft-sediment deformation, clastic dyke, North China Platform

\section{Introduction}

Intraformational limestone breccias and conglomerates are a common phenomenon in mixed carbonate and siliciclastic deposits of Cambrian-Ordovician successions (Sepkoski et al., 1991). They are generally interpreted as a result of rip-up and reworking of thin-bedded limestones by strong currents and waves, most likely induced by storms (e.g., Mount \& Kidder, 1993; Meng et al., 1997; Myrow et al., 2004). However, the vertical orientation of so many clasts in breccias and conglomerates remained a puzzle for a long time, and some discordant geometries (fissure-, funnel-, and mound-like, and less easily defined geometries) cannot be well explained by primary processes. Various secondary processes (i.e., soft-sediment defor- mation) were recently proposed to explain such features as vertical orientation of clasts and discordant geometries of beds (Bouchette et al., 2001; Chough et al., 2001; Kwon et al., 2002; Pratt, 2002; Myrow et al., 2004; Chen et al., 2009a,b, 2010, 2011; Van Loon et al., 2012, 2013; Chen \& Lee, 2013; Chough \& Chen, 2013).

The Furongian (Late Cambrian) Chaomidian Formation in Shandong Province, North China, consists of numerous levels of limestone breccias and conglomerates, many of which have recently been under study (Chen et al., 2009a, b, 2010, 2011; Van Loon et al., 2012, 2013; Chen \& Lee, 2013; Chough \& Chen, 2013). Here some closely related limestone breccias and conglomerates are presented that occur in a grainstone horizon in the middle part of the Chaomidian Formation in the Jiulongshan 
section, Shandong Province, China (Fig. 1). The breccias and conglomerates look similar with respect to their clasts and matrix (both being composed of grainstone), but they bear certain differences in texture and fabric of the clasts and the bed geometry. Although the limestone breccias were described and genetically interpreted in previous studies, the limestone conglomerates, their relationship with breccias, and other storm-induced structures (e.g., gutter casts) were not dealt with in detail, although they are critical for understanding the storm-induced mechanisms that affected ancient carbonate platforms.

The primary objective of the present contribution is therefore to describe in detail the characteristics and relationship of these breccias and conglomerates, as well as other sedimentary structures, in order to make their formative processes clear, and thus to deepen the insights into surface and subsurface reworking of penecontemporaneous carbonate sediments by storm waves and currents.

\section{Geological setting}

The North China Platform was, during the early Palaeozoic, a typical epicontinental basin formed on a stable craton, the Sino-Korean
Block, which covers an area of about $1500 \mathrm{~km}$ from East to West and $1000 \mathrm{~km}$ from North to South (Meng et al., 1997) (Fig. 1). The Cambrian succession contains in Shandong Province a thick succession (approx. $800 \mathrm{~m}$ ) of mixed carbonate and siliciclastic deposits; this succession consists of six lithostratigraphic units (Liguan, Zhushadong, Mantou, Zhangxia, Gushan, and Chaomidian Formations in ascending order) (Fig. 2A). It unconformably overlies a Precambrian granite and metasedimentary rocks, and is overlain by Ordovician dolostones and limestones (Chough et al., 2010; Chen et al., 2012).

The Chaomidian Formation (approx. 200 300 m thick) is assigned to the uppermost lithostratigraphical unit of the Cambrian in Shandong Province (Fig. 2A). It consists mostly of carbonate deposits with minor shales, including limestone and shale/marlstone alternations, thin-bedded lime mudstones, bioturbated wackestones, cross-stratified grainstones, microbialites, and limestone breccias and conglomerates (Chen et al., 2009a, b; Chough et al., 2010; Lee et al., 2010, 2012). The Chaomidian Formation was generally deposited in shallow-marine environments affected by storms that left frequent structures and deposits such as gutter casts, scoured bases, hummocky cross-stratification, and stratified limestone conglomerates (Chen et al., 2011, 2012).
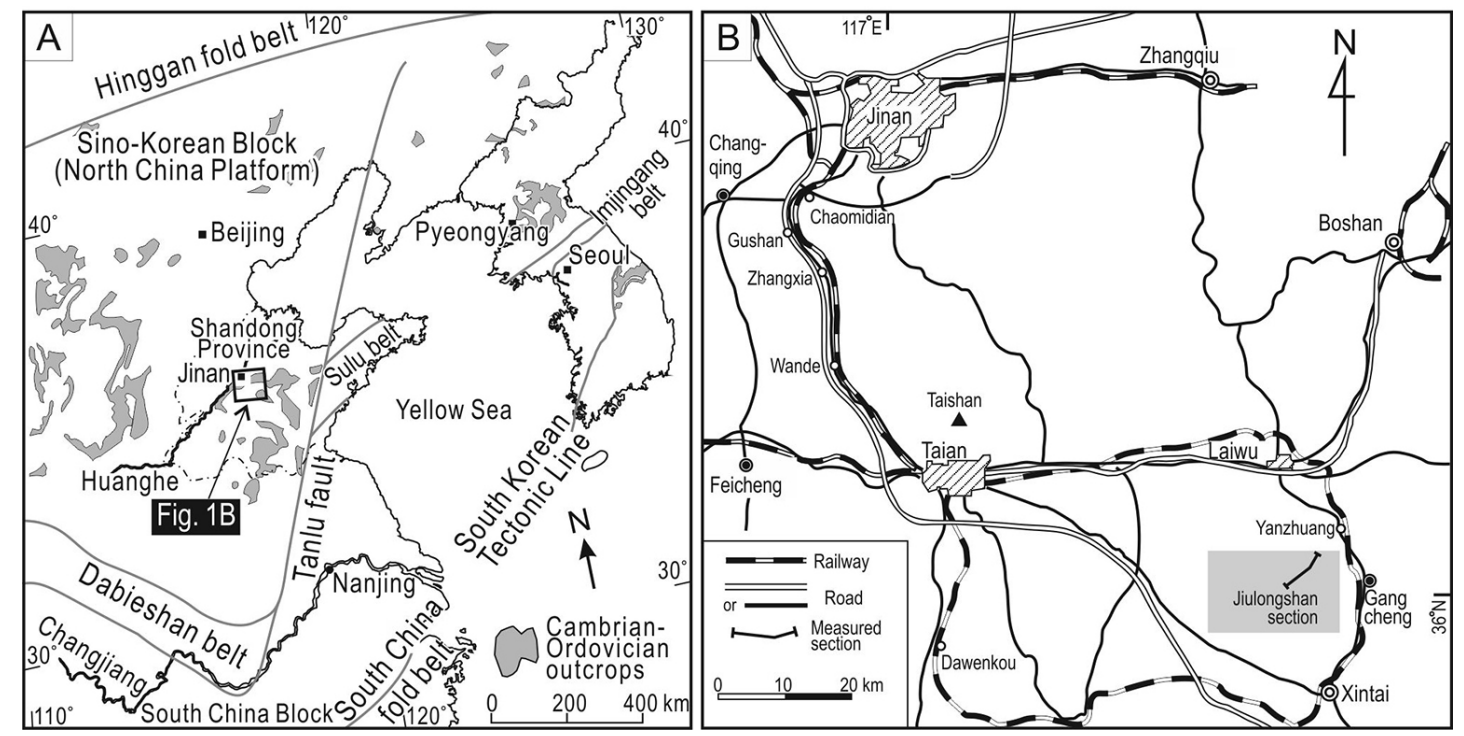

Fig. 1. Location map of the studied section.

A: Schematic geological map of the North China Platform with major tectonic boundaries and distribution of Cambrian-Ordovician outcrops; B: Location of the Jiulongshan section in Shandong Province, China. For location, see Figure 1A. 


\section{Limestone breccias and conglomerates}

The limestone breccias and conglomerates under study occur in a grainstone level (some $1.8 \mathrm{~m}$ thick) in the middle part of the Chaomidian Formation (Fig. 2), which can be laterally traced for at least several kilometres. The level is dominated by hummocky cross-stratified peloidal grainstones (Fig. 2B), which are composed mainly of coarse silt- to very fine sand-size peloids and a small amount of fossil fragments, with a cement of sparry calcite. The grainstone beds are partly laterally continuous, partly discontinuous, and vary in thickness from a few decimetres to two metres. The thick grainstone beds are commonly amalgamated with internal truncational boundaries (Fig. 3A). Individual grainstone layers are undulatory or wavy, and vary in thickness later- ally from a few $\mathrm{mm}$ to two centimetres. The grainstone beds are partly bioturbated with vertical burrows (Skolithos, 1-5 cm deep). The limestone breccias and conglomerates are described and interpreted in detail below.

\subsection{Limestone conglomerates}

\subsubsection{Description}

The limestone conglomerates have a framework of monomictic to oligomictic clasts of peloidal grainstone (Fig. 3). The beds are intercalated between hummocky cross-stratified peloidal grainstones, and are laterally traceable for at least several tens of metres. The conglomerates are either clast-supported or matrix-supported, and sometimes show low-angle cross-stratification. Cross-stratified conglomerates are commonly matrix-support-
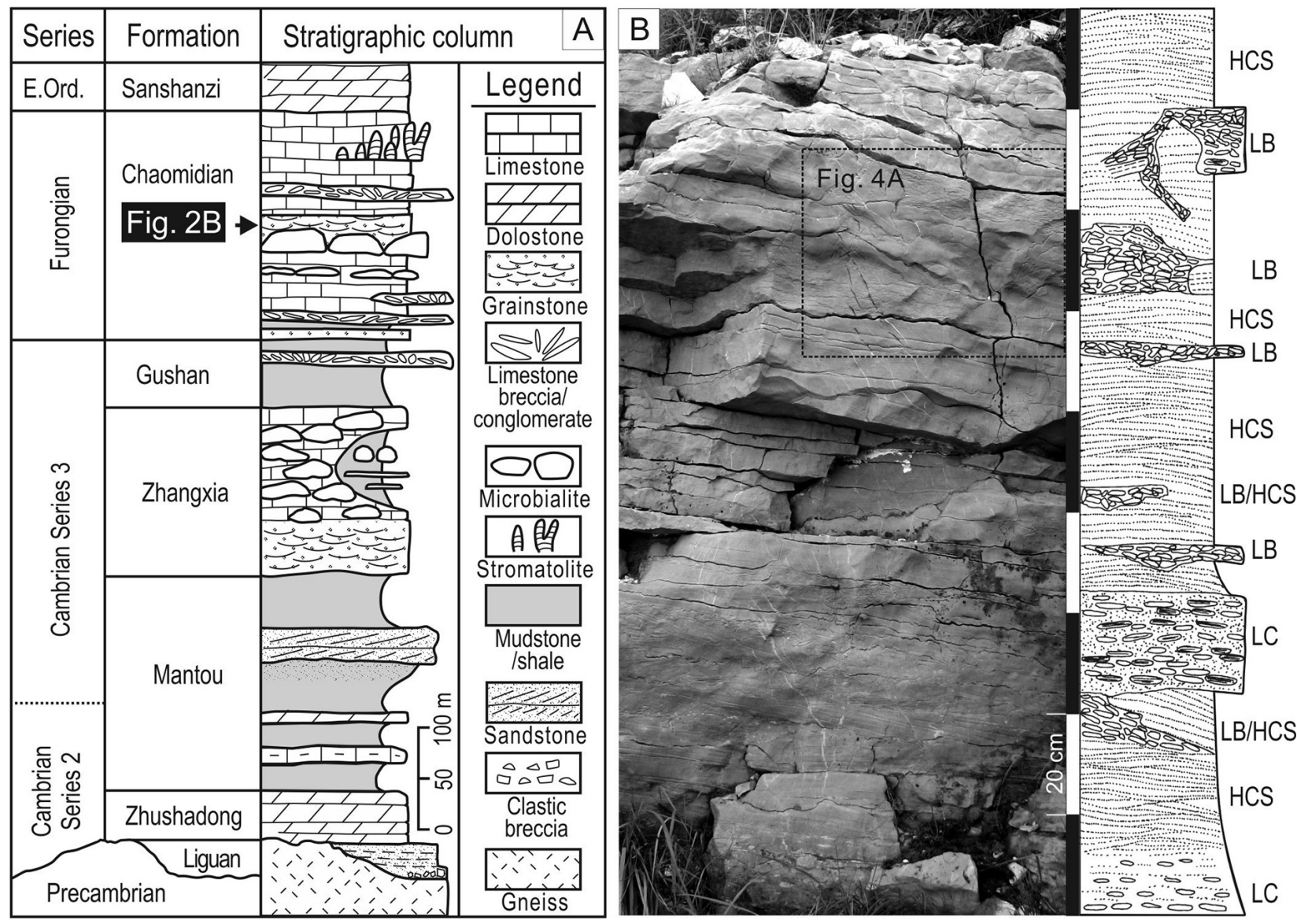

Fig. 2. Schematic stratigraphy of the Cambrian in Shandong Province and sedimentary log of the interval under study. A: Chrono- and lithostratigraphy of the Cambrian succession; B: Photograph and detailed sedimentary log of the grainstone-dominated interval under study. For stratigraphic position, see Figure 2A. HCS = hummocky cross-stratified grainstone; $\mathrm{LB}=$ limestone breccia; $\mathrm{LC}=$ limestone conglomerate. 

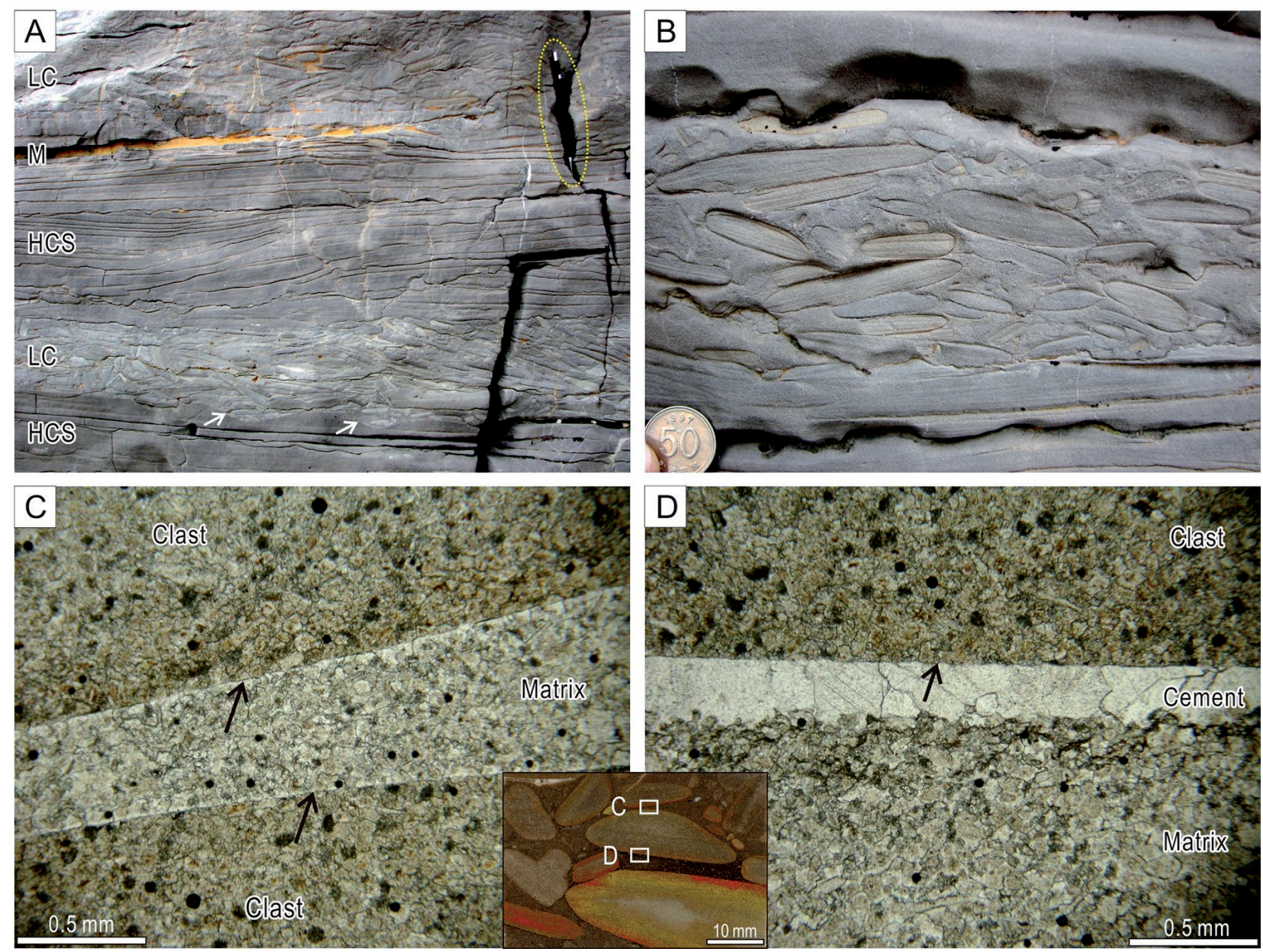

Fig. 3. Limestone conglomerates within hummocky cross-stratified grainstones.

A: Alternation of limestone conglomerate (LC) layers and hummocky cross-stratified grainstone (HCS) layers, locally intercalated between thin dolomitic marlstone $(\mathrm{M})$ layers. The lower limestone conglomerate layer contains imbricated clasts and shows a sharp, erosional boundary (arrows); B: Close-up of well-rounded flat-pebble clasts of a limestone conglomerate; C: Thin section of a well-rounded flat-pebble conglomerate. Note that the matrix has a similar microscopic texture as the clasts. Arrows indicate the sharp boundaries between clasts and matrix; D: Thin section of sparry calcite cement below a well-rounded pebble. Inset: Polished slab used for preparing the thin sections, showing the location of Figures $3 \mathrm{C}$ and $3 \mathrm{D}$.

ed, with clasts parallel to the forests of the cross-stratification. The conglomerate beds are underlain by peloidal grainstone with a sharp irregular lower boundary and overlain by peloidal grainstone with either a gradational or a sharp boundary (Fig. 3A).

The clasts have long axes of a few centimetres and consist of laminated peloidal grainstone (Fig. 3B); they are well rounded and sorted, and mostly flat-lying or imbricated and rarely edgewise (Fig. 3A, B). The matrix has the same texture as the clasts and the hummocky cross-stratified grainstones, which are composed mainly of peloids, fossil fragments (among other fossils trilobites and echino- derms), and sparry calcite cement (Fig. 3C, D). Sparry calcite cement is sometimes present below the clasts (Fig. 3D).

\subsubsection{Interpretation}

The limestone conglomerates formed by transportation and deposition of rip-ups of (semi)consolidated limestone layers (cf. Kreisa, 1981; Markello \& Read, 1981; Sepkoski, 1982; Sepkoski et al., 1991; Mount \& Kidder, 1993; Vierek, 2007, 2010). The stratified conglomerates were probably reworked by strong currents and/or waves that were most likely induced by storms. The coarse-grained matrix is also suggestive of high-energy conditions. 
The imbrication of the clasts resulted from modification by unidirectional currents, whereas flat-lying clasts were reworked by waves. The sporadic edgewise orientation of pebbles might have resulted from powerful oscillatory currents (Futterer, 1982) or storm-generated combined flows (Mount \& Kidder, 1993).

The sharp contact between clasts and matrix indicates that the clasts were well cemented prior to brecciation and re-deposition. The sparry calcite cement below the clasts formed during early diagenesis in cavities sheltered by re-deposited clasts.

\subsection{Limestone breccias}

In addition to the limestone breccias (grainstone-matrix breccias) under study, it should be noted here that another type of breccias (marlstone-matrix breccias) also occurs locally in the level under study (Chen \& Lee, 2013). These breccias are characterised by pebble- to cobble-sized peloidal grainstone clasts in a dolomitic marlstone and/or laminated wackestone matrix; they have commonly mound-shaped bed geometries, which makes them clearly distinguishable from the breccias under study.

These breccias have been the object of several studies, and were interpreted as a result of heterogeneous deformation of carbonate sediments and argillaceous sediments (Chen \& Lee, 2013; Chough \& Chen, 2013; Van Loon et al., 2013), and therefore will not be dealt with in the present study; the present study deals exclusively with the breccias that have a grainstone matrix and that are dealt with below.

\subsubsection{Description}

The limestone breccias are either clast-supported or matrix-supported. They consist of monomictic grainstone clasts with a disorganised fabric in a grainstone matrix (Fig. 4A). The clasts are identical in colour, texture, structures and composition to the adjacent hummocky cross-stratified grainstone. The grainstone clasts are mainly composed of peloids, small amounts of fossil fragments (trilobites, algae, and brachiopods) and mosaic sparry calcite. The peloids and fossil fragments are about 0.05 to $0.15 \mathrm{~mm}$ in size (coarse silt to fine sand). The grainstone matrix is mainly composed of elongated sparry calcite grains which are mostly aligned parallel to each other (Fig. $4 \mathrm{~B})$. The calcite grains are partly present in the groundmass of micro-sparry calcite. Rhombic dolomite crystals occasionally occur in the matrix. The clasts are mostly of granule to pebble size (long axes of several $\mathrm{mm}$ to $\mathrm{cm}$ ) and rarely of cobble size; they are generally poorly sorted and show elongated or irregular shapes with subangular to subrounded edges. Well preserved lamination is present in some relatively large clasts (Fig. 4A, C, D).

Discordant breccia bodies are usually centimetre to decimetre wide in cross-section, and commonly change into grainstones with distinct, irregular boundaries (Fig. 4A, C). They show various geometries such as funnel, channel, fissure (crack), and less easily defined shapes, and are locally connected, forming a reticulate network (Fig. 4A, C).

Small-scale clastic dykes are often associated with these breccias (Fig. 4E, F). In several cases, they extend upward and are connected with discordant breccias (Fig. 4E). The source of the dykes is hardly traceable; in many cases they demise downwards within the grainstone. They are steeply inclined to vertical pipe-shaped structures and occasionally are bifurcated or branched in vertical section. The walls of the dykes which cut through adjacent undeformed grainstone are generally straight to slightly sinuous. The dykes are several millimetres wide and a centimetre to a decimetre thick. Inside the clastic dykes massive or crudely laminated fine grainstone is present (Fig. 4F). Grainstone clasts are locally present in the dykes.

\subsubsection{Interpretation}

The limestone breccias were formed by differential liquefaction and fluidisation during early diagenesis (Chen et al., 2009b, 2011; Chen \& Lee, 2013). Under external force, carbonate grains experience selective liquefaction and subsequent fluidisation due to heterogeneous cementation (Chen et al., 2009b; Chen \& Lee, 2013). Increased pore-fluid pressure broke-up the weakly cemented aggregates of grains, and 

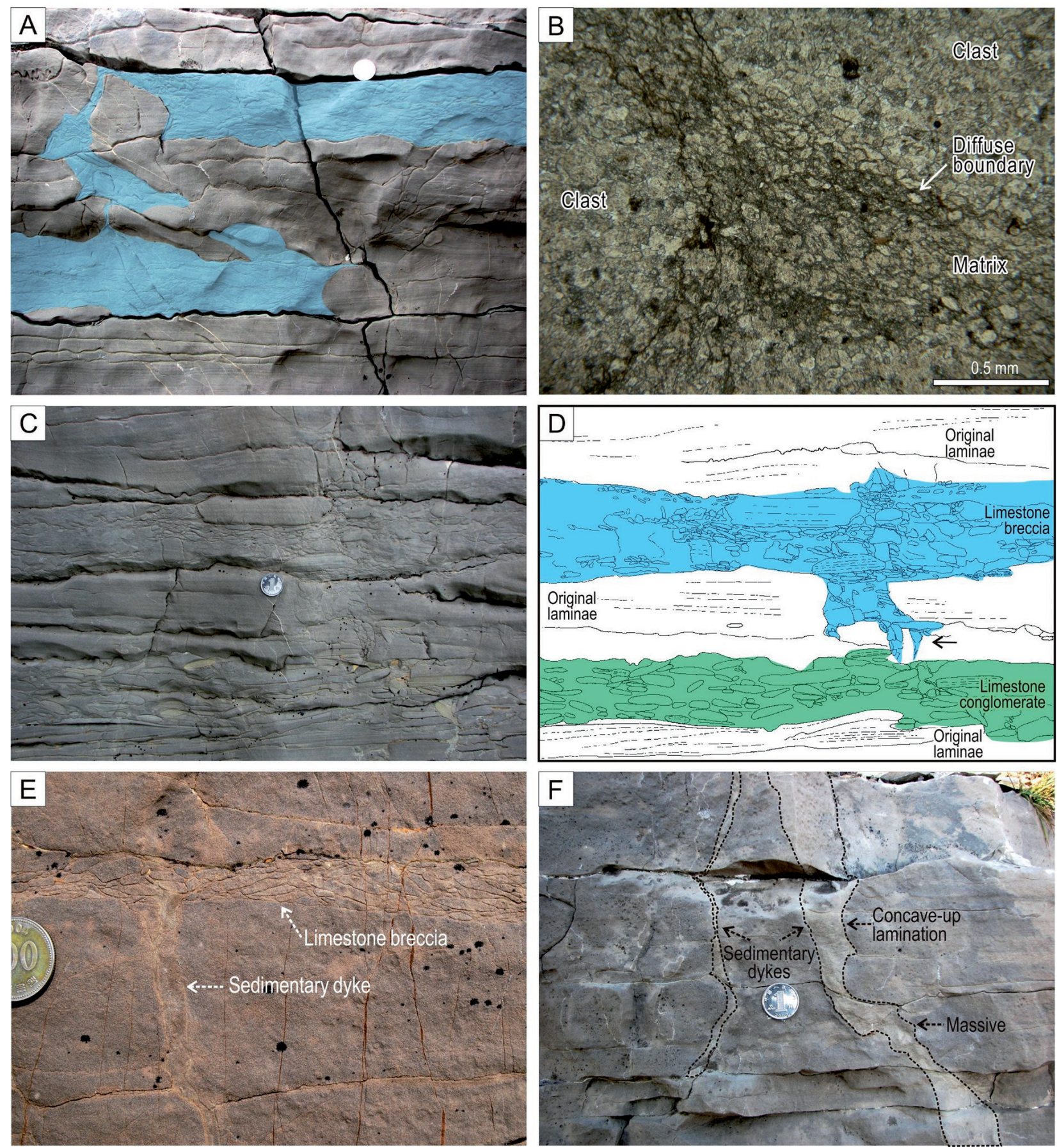

Fig. 4. Limestone breccias.

A: Limestone breccias (shaded colour) with discordant geometry, which end abruptly to laminated grainstone; B: Thin section showing diffuse boundary between clast and matrix of elongated calcite grains with a micro-sparite groundmass; C-D: Field photograph and line drawing of discordant limestone breccias in the upper part and well-rounded pebble limestone conglomerates in the lower part. The arrow in Figure 4D shows a dyke-like conduit between the conglomerates and breccias; E: Clastic dyke connected with limestone breccia; F: Clastic dykes with either massive or crudely laminated sediment inside.

resulted in liquefaction. The liquefied sediments and pore water became under increasing pressure, and finally escaped upwards due to the increased pressure by an external force. Consequently, the upward influx of liquefied sediments and pore water led to restricted flu- 
idization of the sediments. Clastic dykes resulted from upward flowage of either liquefied or fluidized sediments that came most likely from below. The upward injection of the fluid produced various crude laminae inside the dykes due to fluid drag and intrusion. Discordant breccias formed due to differential liquefaction or fluidisation of the heterogeneously cemented sediment: liquefied/fluidised portions formed matrix material, whereas unliquefied, well-cemented sediment formed clasts. The upward escape of pore water and fluidised sediment under increased stress by external force resulted in random dislocation of the clasts, which formed a disorganised internal fabric (horizontal, inclined, or vertical).

\section{Discussion: deposition, erosion, and deformation by storm waves and currents}

Storm-induced waves and currents are important sedimentary agents that episodically and catastrophically erode, deposit, and deform sedimentary strata. The dynamics of storm-induced currents are complex and such currents may form a wide range of sedimentary structures such as hummocky cross-stratification, flat pebbles, and pot and gutter casts (e.g., Aigner, 1985; Myrow \& Southard, 1991, 1996; Myrow, 1992; Molina et al., 1997) (Figs 5 and 6). Hummocky cross-stratification is a rep-
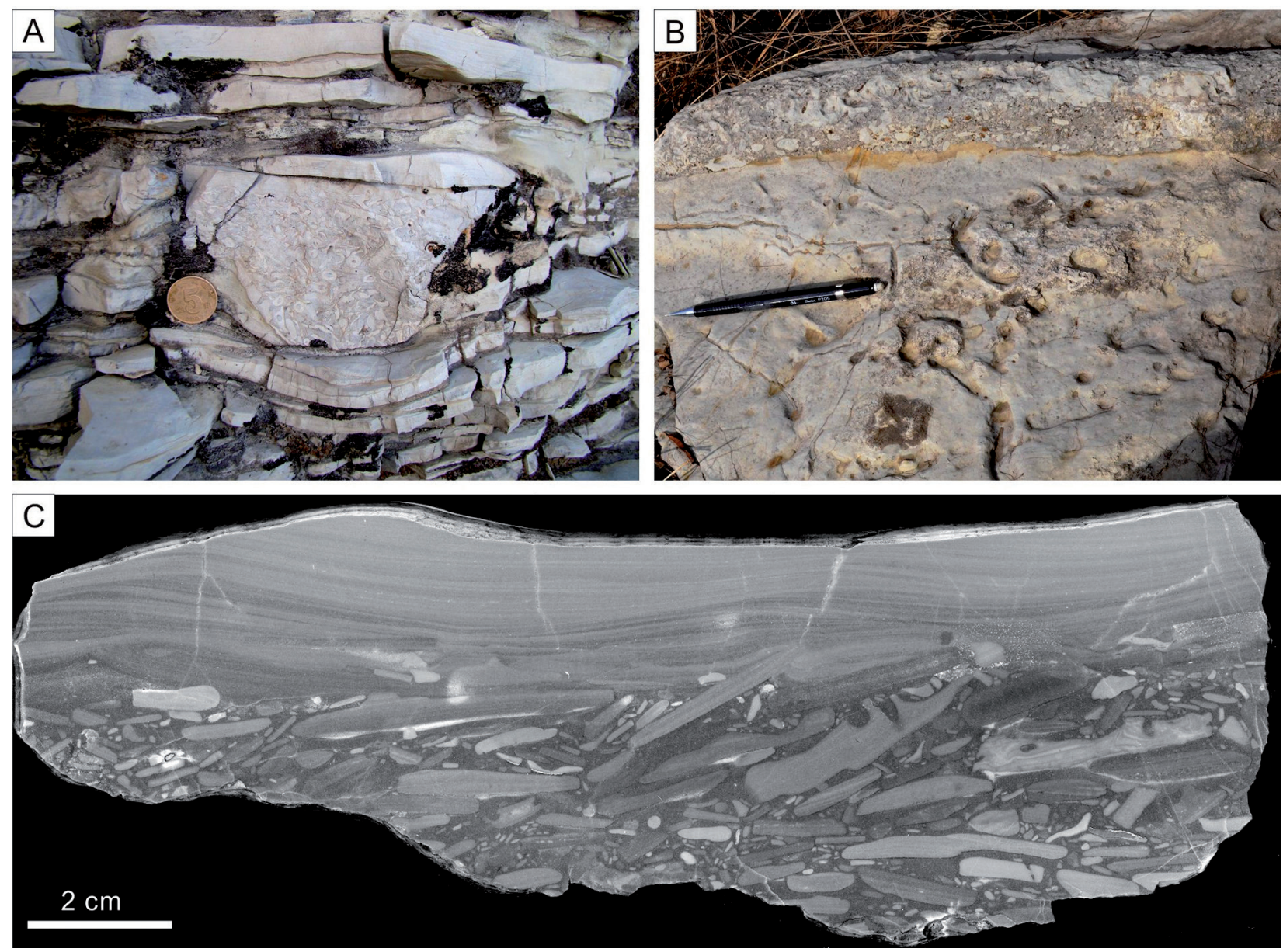

Fig. 5. Other sedimentary structures formed by storm-induced currents in relatively deeper settings (most likely below storm-wave base) of the Chaomidian Formation. These structures occur stratigraphically below the studied interval. A: Vertical section of a gutter cast filled with intraclasts and coarse-grained matrix. The gutter cast shows a channel-like geometry in thin-bedded lime-mudstone; B: Lower bedding plane of a gutter cast in thin-bedded lime-mudstone, filled with intraclasts and a coarse-grained matrix; C: Imbricated limestone conglomerate capped by fine ripple cross-lamination. 

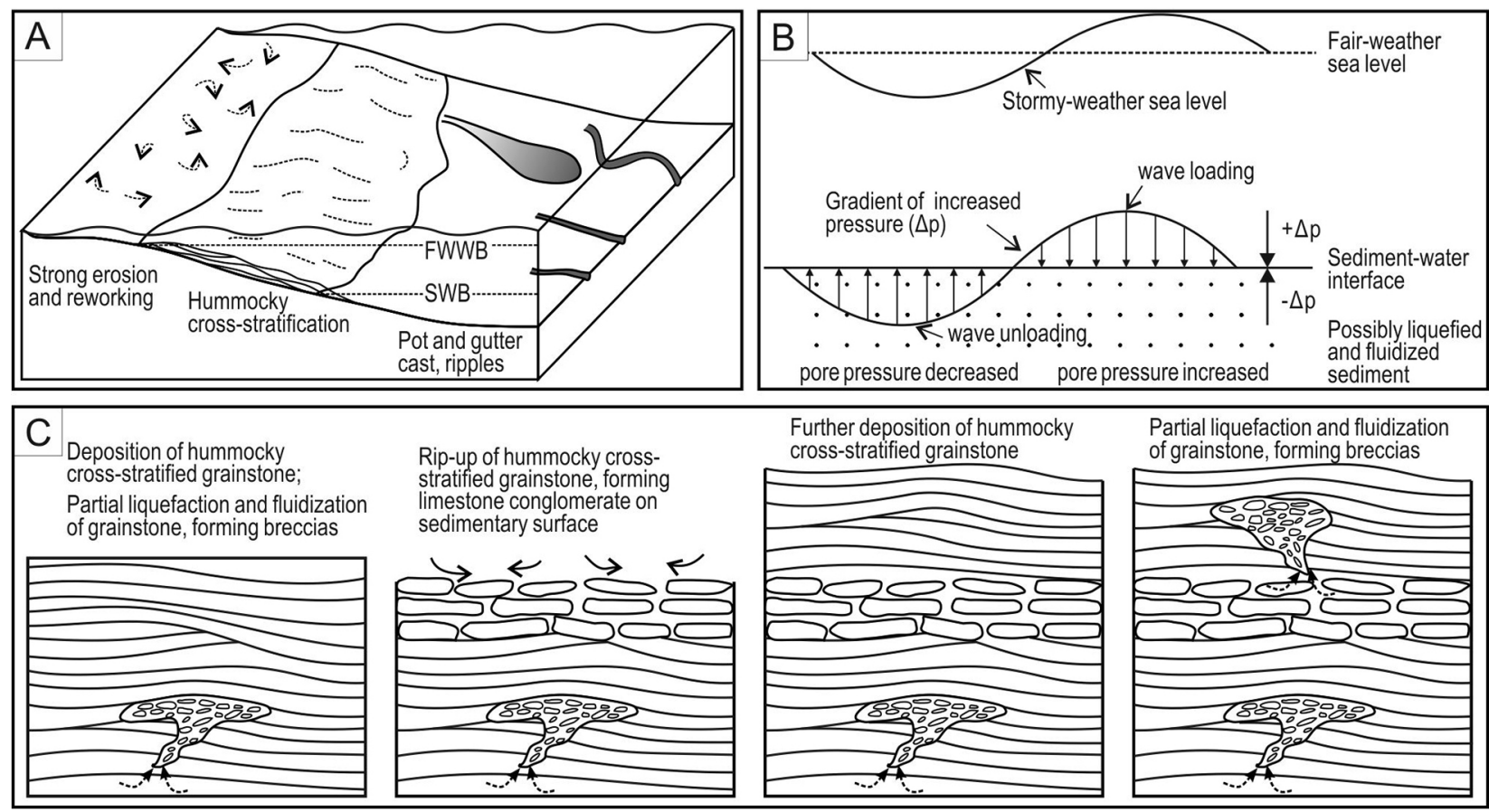

Further deposition of hummocky cross-stratified grainstone

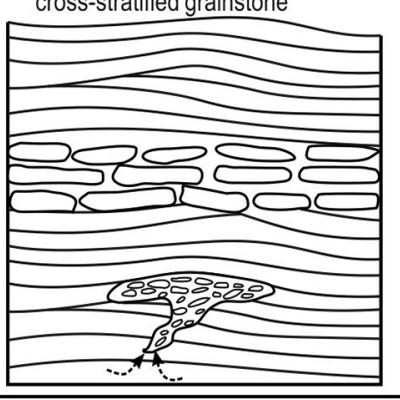

Partial liquefaction and fluidization of grainstone, forming breccias

Fig. 6. Schematic model of storm-induced erosion, deposition, and deformation.

A: Schematic depositional model during storms; B: Cyclically fluctuating pressure during storm waves (modified after Tsui \& Helfrich, 1983; Alfaro et al., 2002); C: Genetic model of the limestone conglomerates and breccias by surface erosion and rip-up and subsurface soft-sediment deformation, respectively.

resentative sedimentary structure formed by storm-induced combined flows (Allen, 1985; Nøttvedt \& Kreisa, 1987; Arnott \& Southard 1990; Cheel \& Leckie, 1993).

Storm waves and currents may erode and transport coarse-grained sediments (e.g., intraclasts and carbonate grains) from the shoreline and upper shoreface to relatively deep environments that are usually below the fair-weather wave base and above the storm-wave base (Fig. 6A). Hummocky cross-stratified grainstone beds were formed by oscillatory wave-dominated combined currents with waning currents during accumulation of sediments. Thick hummocky cross-stratified grainstone units are suggestive of energetic and frequent storms and proximal depositional environments close to the sources of sediments (Duke, 1990). The local occurrence of Skolithos is suggestive of post-storm colonization of organisms on the coarse-grained substrate of the shoreface (Posamentier \& Walker, 2006). During severe storms, erosion may also occur, reworking the previously deposited peloidal grainstones that were re-deposited as limestone conglomerates (Fig. 6C). Further basinwards, gutter casts, limestone conglomerates, and small-scale ripple-cross-lamination formed by erosion and deposition by sediment gravity flows (Figs 5 and 6A).

On the other hand, during stormy-weather conditions, when a wave (up to several hundreds of metres in wave length and decimetres in wave height) passes over sediments, the overburden pressure to the sediments is incrementally increased (Tsui \& Helfrich, 1983). The increased pressure gradient fluctuates with the same period as the waves with a phase lag which is maximum at the sediment/water interface and decreases downwards within the sediment column (Fig. 6B). Soft sediments near the sediment/water interface that are not well compacted or cemented can be substantially eroded and suspended in the water column. The relatively deeper-buried sediment (centimetres to metres below the sediment/water interface where early cementation occurs), however, will be liquefied when the pore-fluid pressure passes the failure threshold (e.g., Molina et al., 1998; Alfaro et al., 2002). Subsequent fluidisation can be triggered by the influx of pore water and liquefied sediments. 
In carbonate settings, liquefaction and fluidisation will be heterogeneous, due to partial cementation of carbonate sediments: uncemented or weakly cemented sediments will be liquefied and fluidised, forming a matrix for the breccias, whereas well cemented sediments will not be liquefied, forming the clasts of the breccias (e.g., Bouchette et al., 2001; Chen et al., 2009b; Chen \& Lee, 2013) (Fig. 6C).

One cannot rule out that catastrophic events such as earthquakes may have coincidently occurred during storms and that resulting shock waves also have deformed the sediments. However, earthquakes are for the breccias under study not a likely trigger mechanism for the following reasons: (1) the North China Platform formed on a stable craton during the Late Cambrian, which was tectonically and seismically quiet (Meng et al., 1997); (2) the limestone breccias and the associated clastic dykes, which resulted from differential liquefaction and fluidisation, occur only in hummocky cross-stratified peloidal grainstones (facies-dependent) (cf. Molina et al., 1998; Alfaro et al., 2002; Owen et al., 2011). In addition, the characteristics of the deformation structures are different from those of seismically induced soft-sediment deformation structures such as convolute folds, ball-and-pillow structures, and dish-and-pillars (e.g., Van Loon, 2009; Gibert et al., 2011). Nor is there any evidence of substantial gravity-induced sediment failure on a slope. Instead, the subtropical to tropical climate conditions of the North China Platform during the Cambrian, the common occurrence of storm-related features (i.e., hummocky cross-stratified grainstones, stratified limestone conglomerates, and erosional bases), and the relatively small-scale ( $\mathrm{cm}$ to $\mathrm{dm}$ ) and restricted (a few $\mathrm{km}^{2}$ in surface area) presence of deformation structures suggest that storm events were the most probable triggers.

\section{Conclusions}

Limestone breccias and conglomerates occur abundantly in the Furongian Chaomidian Formation of the North China Platform. Some grainstone breccias and conglomerates co-oc- cur in a hummocky cross-stratified grainstone interval in the middle part of the formation. The limestone conglomerates contain either flat-lying or imbricated clasts with rounded edges, which were formed by surface erosion and ripup of thin grainstone layers by storm-induced waves and currents. The limestone breccias contain subangular clasts and show discordant geometries (fissure-, funnel-, and mound-like, and less easily defined geometries); they are often associated with clastic dykes. The breccias and dykes are characteristic of early-diagenetic soft-sediment deformation structures that were formed by local differential liquefaction and fluidisation of heterogeneously cemented carbonate grains. The subtropical to tropical climate conditions of the North China Platform and the common occurrence of storm deposits suggest that storm-wave loading (subsurface reworking) was the most probable trigger accounting for the sediment deformation. This deepens the insight into not only the genesis of limestone breccias and conglomerates, but also the reworking mechanisms of storm waves on platform carbonates.

\section{Acknowledgements}

This study was financially supported by the National Natural Science Foundation of China (41302077). I greatly acknowledge the helpful discussions on the subject with Prof. S.K. Chough, Prof. Z. Han, Prof. A.J. van Loon, Dr H.S. Lee, Dr J. Woo, Dr J.-H. Lee, and Dr S.-B. Lee for the past years. I also thank the two anonymous reviewers for their helpful comments on the earlier version of the manuscript.

\section{References}

Aigner, T., 1985. Storm depositional systems: dynamic stratigraphy in modern and ancient shallow-marine sequences. Lecture Notes in Earth Science 3. Springer-Verlag (Berlin), 174 pp.

Alfaro, P., Delgado, J., Estévez, A., Molina, J.M., Moretti, M. \& Soria, J.M., 2002. Liquefaction and fluidization structures in Messinian storm deposits (Bajo Segura Basin, Betic Cordillera, southern Spain). International Journal of Earth Sciences 91, 505-513.

Allen, P.A., 1985. Hummocky cross-stratification is not produced purely under progressive gravity waves. Nature 313, 562-564. 
Arnott, R.W.C. \& Southard, J.B., 1990. Exploratory flowduct experiments on combined-flow bed configurations, and some implications for interpreting stormevent stratification. Journal of Sedimentary Petrology 60, 211-219.

Bouchette, F., Seguret, M. \& Moussine-Pouchkine, A., 2001. Coarse carbonate breccias as a result of water-wave cyclic loading (uppermost Jurassic - SouthEast Basin, France). Sedimentology 48, 767-789.

Cheel, R.J. \& Leckie, D.A., 1993. Hummocky cross-stratification. Sedimentology Reviews 1, 103-121.

Chen, J. \& Lee, H.S., 2013. Soft-sediment deformation structures in Cambrian siliciclastic and carbonate storm deposits (Shandong Province, China): differential liquefaction and fluidization triggered by stormwave loading. Sedimentary Geology 288, 81-94.

Chen, J., Chough, S.K., Chun, S.S. \& Han, Z., 2009a. Limestone pseudoconglomerates in the Late Cambrian Gushan and Chaomidian Formations (Shandong Province, China): soft-sediment deformation induced by storm-wave loading. Sedimentology 56, 1174-1195.

Chen, J., Van Loon, A.J., Han, Z. \& Chough, S.K., 2009b. Funnel-shaped, breccia-filled clastic dykes in the Late Cambrian Chaomidian Formation (Shandong Province, China). Sedimentary Geology 221, 1-6.

Chen, J., Han, Z., Zhang, X., Fan, A. \& Yang, R., 2010. Early diagenetic deformation structures of the Furongian ribbon rocks in Shandong Province of China - a new perspective of the genesis of limestone conglomerates. Science China Earth Sciences 53, 241-252.

Chen, J., Chough, S.K., Han, Z. \& Lee, J.-H., 2011. An extensive erosion surface of a strongly deformed limestone bed in the Gushan and Chaomidian formations (late Middle Cambrian to Furongian), Shandong Province, China: Sequence-stratigraphic implications. Sedimentary Geology 233, 129-149.

Chen, J., Chough, S.K., Lee, J.-H. \& Han, Z., 2012. Sequence-stratigraphic comparison of the upper Cambrian Series 3 to Furongian succession between the Shandong region, China and the Taebaek area, Korea: high variability of bounding surfaces in an epeiric platform. Geosciences Journal 16, 357-379.

Chough, S.K. \& Chen, J., 2013. Generation of subsurface injection flow in a carbonate platform. Geosciences Journal 17, 3-8.

Chough, S.K., Kwon, Y.K., Choi, D.K. \& Lee, D.J., 2001. Autoconglomeration of limestone. Geosciences Journal 5, 159-164.

Chough, S.K., Lee, H.S., Woo, J., Chen, J., Choi, D.K., Lee, S.-b., Kang, I., Park, T.-Y. \& Han, Z., 2010. Cambrian stratigraphy of the North China Platform: revisiting principal sections in Shandong Province, China. Geosciences Journal 14, 235-268.

Duke, W.L., 1990. Geostrophic circulation or shallow marine trubidity currents? The dilemma of paleoflow patterns in storm-influenced prograding shoreline systems. Journal of Sedimentary Petrology 60, 870-883.

Futterer, E., 1982. Experiments on the distinction of wave and current influenced shell accumulations. [In:] G. Einsele \& A. Seilacher (Eds): Cyclic and event stratification. Springer-Verlag (Berlin), 175-179.
Gibert, L., Alfaro, P., García-Tortosa, F.J. \& Scott, G., 2011. Superposed deformed beds produced by single earthquakes (Tecopa Basin, California): insights into paleoseismology. Sedimentary Geology 235, 148-159.

Kreisa, R.D., 1981. Storm-generated sedimentary structures in subtidal marine facies with examples from the Middle and Upper Ordovician of southwestern Virginia. Journal of Sedimentary Petrology 51, 823-848.

Kwon, Y.K., Chough, S.K., Choi, D.K. \& Lee, D.J., 2002. Origin of limestone conglomerates in the Choson Supergroup (Cambro-Ordovician), mid-east Korea. Sedimentary Geology 146, 265-283.

Lee, J.-H., Chen, J. \& Chough, S.K., 2010. Paleoenvironmental implications of an extensive maceriate microbialite bed in the Furongian Chaomidian Formation, Shandong Province, China. Palaeogeography, Palaeoclimatology, Palaeoecology 297, 621-632.

Lee, J.-H., Chen, J. \& Chough, S.K., 2012. Demise of an extensive biostromal microbialite in the Furongian (late Cambrian) Chaomidian Formation, Shandong Province, China. Geosciences Journal 16, 275-287.

Markello, J.R. \& Read, J.F., 1981. Carbonate ramp-todeeper shale shelf transitions of an Upper Cambrian intrashelf basin, Nolichucky Formation, Southwest Virginia Appalachians. Sedimentology 28, 573-597.

Meng, X., Ge, M. \& Tucker, M.E., 1997. Sequence stratigraphy, sea-level changes and depositional systems in the Cambro-Ordovician of the North China carbonate platform. Sedimentary Geology 114, 189-222.

Molina, J.M., Ruiz-Ortiz, P.A. \& Vera, J.A., 1997. Calcareous tempestites in pelagic facies (Jurassic, Betic Cordilleras, Southern Spain). Sedimentary Geology 109, 95-109.

Molina, J., Alfaro, P., Moretti, M. \& Soria, J.M., 1998. Soft-sediment deformation structures induced by cyclic stress of storm waves in tempestites (Miocene, Guadalquivir Basin, Spain). Terra Nova 10, 145-150.

Mount, J.F. \& Kidder, D., 1993. Combined flow origin of edgewise intraclast conglomerates: Sellick Hill Formation (Lower Cambrian), South Australia. Sedimentology 40, 315-329.

Myrow, P., 1992. Bypass-zone tempestite facies model and proximality trends for an ancient muddy shoreline and shelf. Journal of Sedimentary Petrology 62, 99115.

Myrow, P.M. \& Southard, J.B., 1991. Combined-flow model for vertical stratification sequences in shallow marine storm-deposited beds. Journal of Sedimentary Petrology 61, 202-210.

Myrow, P.M. \& Southard, J.B., 1996. Tempestite deposition. Journal of Sedimentary Research 66, 875-887.

Myrow, P.M., Tice, L., Archuleta, B., Clark, B., Taylor, J.F. \& Ripperdan, R.L., 2004. Flat-pebble conglomerate: its multiple origins and relationship to metre-scale depositional cycles. Sedimentology 51, 973-996.

Nøttvedt, A. \& Kreisa, R.D., 1987. Model for the combined-flow origin of hummocky cross-stratification. Geology 15, 357-361.

Owen, G., Moretti, M. \& Alfaro, P., 2011. Recognising triggers for soft-sediment deformation: current un- 
derstanding and future directions. Sedimentary Geology 235, 133-140.

Posamentier, H.W. \& Walker, R.G., 2006. Deep-water turbidites and submarine fans. [In:] H.W. Posamentier \& R.G. Walker (Eds): Facies models revisited. SEPM (Tulsa), 399-520.

Pratt, B.R., 2002. Storms versus tsunamis: dynamic interplay of sedimentary, diagenetic, and tectonic processes in the Cambrian of Montana. Geology 30, 423-426.

Sepkoski Jr., J.J., 1982. Flat-pebble conglomerates, storm deposits and the Cambrian bottom fauna. [In:] G. Einsele \& A. Seilacher (Eds): Cyclic and event stratification. Springer-Verlag (Berlin), 371-385.

Sepkoski Jr., J.J., Bambach, R.K. \& Droser, M.L., 1991. Secular changes in Phanerozoic event bedding and the biological overprint. [In:] G. Einsele, W. Richen \& A. Seilacher (Eds): Cycles and events in stratigraphy. Springer-Verlag (Berlin), 298-312.

Tsui, Y. \& Helfrich, S.C., 1983. Wave-induced pore pressure in submerged sand layer. Journal of Geotechnical Engineering 109, 603-618.

Van Loon, A.J., 2009. Soft-sediment deformation structures in siliciclastic sediments: an overview. Geologos $15,3-55$.
Van Loon, A.J., Han, Z. \& Han, Y., 2012. Slide origin of breccia lenses in the Cambrian of the North China Platform: new insight into mass transport in an epeiric sea. Geologos 18, 223-235.

Van Loon, A.J., Han, Z. \& Han, Y., 2013. Origin of the vertically orientated clasts in brecciated shallow-marine limestones of the Chaomidian Formation (Furongian, Shandong Province, China). Sedimentology 60, 1059-1070.

Vierek, A., 2007. Storm-dominated deposition on a Frasnian carbonate platform margin (Wietrznia, Holy Cross Mts., Poland). Geological Quarterly 51, 307-318.

Vierek, A., 2010. Source and depositional processes of coarse-grained limestone event beds in Frasnian slope deposits (Kostomłoty-Mogiłki quarry, Holy Cross Mts., Poland). Geologos 16, 153-168.

Manuscript received: 29 November 2013 Revision accepted: 28 January 2014 